Original Article

\title{
Pengelolaan Obat di Dinas Kesehatan Kabupaten Lampung Timur Provinsi Lampung
}

\section{Drug Management at the Health Office of East Lampung Regency, Lampung Province}

\author{
Hajati Br. Tumangger*, Kodrat Pramudho, Noviansyah, Atikah Adyas \\ Prodi Magister Kesehatan Masyarakat, Fakultas Kesehatan Masyarakat, Universitas Mitra \\ Indonesia \\ (*haya_ns@yahoo.com)
}

\begin{abstract}
ABSTRAK
Penelitian ini bertujaun untuk mengetahui gambaran pengeloaan obat di Dinas Kesehatan Kabupaten Lampung Timur tahun 2020 terutama perencanaan, pengadaan dan distribusi obat ke puskesmas. Metode penelitian ini adalah metode penelitian kualitatif dengan pendekatan analitik. Penelitian ini dilaksanakan di Dinas Kesehatan Kabupaten Lampung Timur. Penelitian ini dilaksanakan pada bulan juni sampai dengan Agustus 2021. Teknik pengumpulan data dilakukan dengan observasi (pengamatan langsung), wawancara mendalam (in-depth interview), telaah dokumen dan Focus Group Discussion (FGD). Hasil penelitian didapatkan perencanaan obat di Dinas Kesehatan Kabupaten Lampung Timur sudah sesuai dengan Permenkes No.HK. 01.07/MENKES/813/2019 tentang Formularium Nasional tetapi penghitungan jumlah kebutuhannya belum sesuai kebutuhan puskesmas. Pengadaan obat di Dinas Kesehatan Kabupaten Lampung Timur sudah sesuai dengan PMK No.63/2014 Tentang Pengadaan Obat Berdasarkan Katalog Elektronik (E-Catalogue) namun dalam pelaksanaannya terkendala dengan ada beberapa obat yang tidak dapat diadakan atau dibeli karena tidak ada di e-catalog maupun FORNAS.
\end{abstract}

Kata kunci : Pengelolaan Obat, Perencanaan, Pengadaan,

\section{ABSTRACT}

This study aims to find out the description of drug management at the East Lampung District Health Department in 2020, especially the planning, procurement and distribution of drugs to community health centers. This research method is a qualitative research method with an analytical approach. This research was conducted at the East Lampung District Health Office. This research was carried out from June to August 2021. Data collection techniques were carried out by observation (direct observation), in-depth interviews, document review and Focus Group Discussion (FGD). The results showed that the drug planning process at the East Lampung District Health Office was in accordance with Permenkes No.HK. 01.07/MENKES/813/2019 concerning the National Formulary but the calculation of the number of needs is not in accordance with the needs of the puskesmas. The drug procurement process at the East Lampung District Health Office is in accordance with PMK No. 63/2014 concerning Procurement of Drugs Based on Electronic Catalogs (E-Catalogue) but in its implementation it is constrained by some drugs that cannot be procured or purchased because they are not in the e-catalog or FORNAS.

Keywords : Drug management, planning, procurement

https://doi.org/10.33860/jik.v15i3.507

(C) 2021 by the authors. Submitted for possible open access publication under the terms and conditions of the Creative

Commons Attribution (CC BY SA) license (https://creativecommons.org/licenses/by-sa/4.0/). 


\section{PENDAHULUAN}

Obat adalah bahan atau paduan bahanbahan yang digunakan untuk mempengaruhi atau menyelidiki sistem fisiologi atau keadaan patologi dalam rangka penegakkan diagnosis, pencegahan, penyembuhan, pemulihan, peningkatan kesehatan, dan kontrasepsi, termasuk produk biologi. Obat merupakan komponen yang tak tergantikan dalam pelayanan kesehatan ${ }^{1}$. Dalam berbagai upaya pelayanan kesehatan, obat merupakan salah satu unsur penting. Sebagian besar upaya pelayanan kesehatan menggunakan obat dan biaya yang digunakan untuk obat merupakan bagian yang cukup besardari seluruh biaya kesehatan. Diantara berbagai alternatif yang ada, intervensi dengan obat merupakan intervensi yang paling banyak digunakan dalam penyelenggaraan upaya kesehatan ${ }^{2}$. Obat dan perbekalan kesehatan hendaknya dikelola secara optimal untuk menjamin tercapainya tepat jumlah, tepat jenis, tepat penyimpanan, tepatwaktu pendistribusian, tepat penggunaan dan tepat mutunya di tiap unit pelayanan kesehatan ${ }^{1}$.

Kebijakan Pemerintah terhadap peningkatan akses obat diselenggarakan melalui beberapa strata kebijakan yaltu Undang-Undang No. 36 tahun 2009 tentang Kesehatan, Peraturan Pemerintah No. 51 tahun 2009 tentang Pekerjaan Kefarmasian, dan Peraturan presiden nomor 72 tahun 2012 tentang SIstem Kesehatan Naslonal (SKN). SKN 2012 memberikan landasan, arah dan pedoman penyelenggaraan pembangunan kesehatan bagi seluruh penyelenggara kesehatan, baik Pemerlntah Pusat, Provinsi dan Kabupaten/Kota, maupun masyarakat dan dunia usaha, serta pihak lain yang terkait. Salah satu subsistem SKN sesuai Perpres nomor 72 tahun 2012 adalah Subsistem sediaan farmasi, alat kesehatan, dan makanan yaitu pengelolaan berbagai upaya yang menjamin keamanan, khasiat/manfaat, mutu sediaan farmasi, alat kesehatan, dan makanan. Sediaan farmasi adalah obat, bahan obat, obat tradisional, dan kosmetika ${ }^{3}$.

Dalam upaya meningkatkan ketersediaan obat publik dan perbekalan kesehatan yang sangat diperlukan adalah optimalisasi pemanfaatan dana, efektivitas penggunaan serta pengendalian persediaan dan pendistribusian dari Unit Pengelola Obat/Gudang Farmasi Kabupaten/ Kota ke Unit
Pelayanan Kesehatan ${ }^{2}$. Pengelolaan obat publik dan perbekalan kesehatan meliputi kegiatan perencanaan, pengadaan, penerimaan, penyimpanan dan distribusi, pencatatan dan pelaporan, sertasupervisi dan evaluasi pengelolaan obat ${ }^{1}$.

Penelitian Ummi Kalsum tahun 2018 menjelaskan bahwa di Dinas Kesehatan Kabupaten Pelalawan Provinsi Riau persentase ketersediaan obat sebesar $75,78 \%$, sementara itu Direktorat Jendral Kefarmasian dan Alkes Kemenkes RI menetapkan target pencapaian ketersediaan obat adalah $90 \%$ pada tahun 2018 dan $95 \%$ tahun $2019^{4}$. Hasil penelitian Asnawi (2019) diketahui bahwa perencanaan obat di puskesmas Wolaang setiap bulannya telah disesuaikan dengan penggunaan obat yang tercatat di LPLPO dan untuk pemantauan dan evaluasi Puskesmas Wolaang hanya melakukan pemantauan untuk obat-obat yang tidak terpakai untuk tidak dibuatkan permintaan pada bulan berikutnya, dan puskesmas Wolaang tidak melakukan evaluasi untuk pengelolaan obat $^{5}$.

Dampak apabila pengelolaan obat tidak dilaksanakan dengan baik maka ketersediaan obat di unit pelayanan kesehatan tidak akan terpenuhi sesuai dengan yang diharapkan seperti terjadi kekosongan (stock out), kekurangan stock obat (under stock) atau kelebihan stock obat (over stock) yang dapat menyebabkan terhambatnya pelayanan obatobatan kepada pasien maupun terjadinya penumpukan obat yang dapat menyebabkan obat kadaluarsa. Oleh karena obat merupakan komponen yang esensial dari suatu pelayanan kesehatan maka diperlukan pengelolaanobat yang baik dan benar serta efektif dan efisien secara berkesinambungan.

Hasil observasi peneliti di Seksi Kefarmasian Dinas Kesehatan Kabupaten Lampung Timur dan beberapa Puskesmas di Kabupaten Lampung Timur menunjukkan bahwa masih terjadi kelebihan persediaan obat (over stock) namun di sisi lain terjadi kekurangan persediaan obat (understock), bahkan ada beberapa item obat yang persediaannya kosong (stock out) dan beberapa kali terjadi keterlambatan distribusi obat dari Dinas Kesehatan Kabupaten Lampung Timur, hal ini mencerminkan ketidaktepatan perencanaan kebutuhan obat dan belum baiknya sistem distribusi serta pengelolaan yang belum efektif dan efisien.

Penelitian ini bertujaun untuk mengetahui 
gambaran pengelolaan obat di Dinas Kesehatan Kabupaten Lampung Timur tahun 2020 terutama perencanaan dan pengadaan obat.

\section{METODE PENELITIAN}

Metode penelitian ini adalah metode penelitian kualitatif dengan pendekatan analitik. Penelitian ini dilaksanakan di Dinas Kesehatan Kabupaten Lampung Timur. Penelitian ini dilaksanakan pada bulan juni sampai dengan Agustus 2021.

Sumber informasi yang merupakan objek dari penelitian ini adalah Seksi Kefarmasian Dinas Kesehatan Kabupaten Lampung Timur. Informan dari penelitian ini adalah Kepala Seksi Kefarmasian, semua staf yang berhubungan dalam perencanaan dan pengadaan obat, dan pengelola obat di Puskesmas. Informan lain adalah stakeholder dalam pengadaan obat yaitu anggota komisi 4 DPRD Kabupaten Lampung Timur, Bappeda dan BPKAD Kabupaten Lampung Timur. Telaah dokumen pada seksi kefarmasiaan Dinas Kesehatan kabupaten Lampung Timur, Laporan Permintaan dan Lembar Penerimaan Obat (LPLPO) serta rencana kebutuhan obat (RKO) juga merupakan sumber informasi penting dalam penelitian ini. Dalam penelitian kualitatif ini yang menjadi instrumen atau alat penelitian adalah peneliti sendiri. Teknik pengumpulan data dilakukan dengan observasi (pengamatan langsung), wawancara mendalam (in-depth interview), telaah dokumen dan FGD sebagai triangulasi.

Teknik analisis data dalam metode kualitatif juga dilakukan dalam tiga tahap yaitu (Lapau, 2012) : 1) Analisis data sebelum di lapanagan; 2) Analisis data selama di lapangan; 3) Analisis data setelah di lapangan ${ }^{6}$

Data yang telah berhasil dikumpulkan kemudian di lakukan analisis untuk mengetahui bagaimana perencanaan dan pengadaan obat di Dinas Kesehatan Kabupaten lampung Timur. Selanjutnya akan diinventarisir apa saja yang menjadi masalah dan kendala dari perencanaan dan pengadaan obat di Dinas Kesehatan Kabupaten lampung Timur.

\section{HASIL}

\section{Perencanaan \\ Input}

Wawancara dengan Kepala Dinas Kesehatan Kabupaten Lampung Timur mengenai Man atau sumber daya manuasia yang terlibat dalam perencanaan obat di Dinas Kesehatan :

"Yang terlibat dalam perencanaan obat adalah Kabid Kefarmasian, Kasi Kefararmasian, apoteker dan staf di dinkes serta pengelola obat puskesmas".

Hasil wawancara dengan Kepala Seksi Kefarmasian mengenai Man atau sumber daya manusia yang terlibat dalam proses perencanaan obat di Dinas Kesehatan Kabupaten Lampung Timur :

"Yang terlibat dalam perencanaan obat adalah Pengelola obat puskesmas, Dokter Puskesmas dan tim perencanaan obat Dinas".

Dari hasil FGD, pengelola obat Puskesmas Jabung menyatakan :

"Konsul dengan dokter obat yang dibutuhkan apa, melihat data 2 penggunaan obat sebelumnya".

Dari hasil telaah dokumen bahwa pada dokumen perencanaan obat atau RKO puskesmas ada tanda tangan pengelola obat puskesmas, dokter puskesmas mengetahui kepala puskesmas.

Berdasarkan wawancara tersebut dapat disimpulkan bahwa sumber daya manusia di puskesmas dalam perencanaan obat adalah pengelola obat dan dokter puskesmas, sedangkan sumber daya manusia di Dinas Kesehatan adalah tim perencanaan obat Dinas Kesehatan yang terdiri dari Kepala Seksi Kefarmasian, staf perencanaan (Apoteker) dan Pengelola Program Dinas Kesehatan.

Hasil wawancara mengenai Money atau sumber dana anggaran untuk perencanaan obat tahun 2020 dengan Kepala Dinas Kesehatan Kabupaten Lampung Timur menyatakan bahwa:

"Sumber anggaran untuk pengadaan obat sebetulnya dari $A P B N$ dan $A P B D$, tapi untuk dana $A P B D$ di refocusing untuk penanganan covid sehingga anggaran untuk pengadaan obat PKD tahun 2020 bersumber dari $D A K(A P B N)$ “.

Demikian halnya dengan pernyataan Kepala Seksi Kefarmasian terkait sumber dana perencanaan dan pengadaan obat, sebagai berikut :

"Sumber pengadaan obat tahun 2020 adalah dari DAK / APBN".

Wawancara dengan stakeholder yaitu Kepala Bappeda :

"Bappeda institusi perencana, merencanakan sesuai usulan Dinas tentunya 
disesuaikan dengan kemampuan daerah, prosesnya Dinas Kesehatan mengusulkan kepada TAPD ( Tim Anggaran Peerintah Daerah) didalamnya ada Bappeda, Bappeda yang menyususn dokumen perencanaan RKPD kemudian dibahas dalam tim anggaran pemerintah daerah setelah itu disusun dokumennya kemudian disampaikan kepada $D P R D$ untuk di bahas nanri keularannya adalah APBD Lampung Timur".

Dari hasil wawancara dan FGD tersebut dapat disimpulkan bahwa anggaran untuk perencanaan obat adalah dari dana DAK ( APBN) dan APBD

Wawancara dengan Kepala Dinas Kesehatan mengenai Methode perencanaan obat yang digunakan di Dinas Kesehatan Kabupaten Lampung:

"Perencanaan obat di Dinkes Lamtim dilakukan sesuai dg SOP mulai dari usulan RKO Puskesmas sampai dengan RKO Dinkes".

Dari Hasil FGD, pengelola obat puskesmas Sekampung menjelaskan mengenai perencanaan :

"Berdasarkan kebutuhan, urgensi, dan esensial obatnya, berdasarkan FORNAS, yang diluar fornas bila dibutuhkan baru di minta".

Hasil observasi dan telaah dokumen terdapat rekapan RKO Puskesmas di bagian perencanaan. Dari beberapa keterangan tersebut diatas dapat disimpulkan bahwa perencanaan mengacu pada SOP Perencanaan dan FORNAS.

Hasil observasi mengenai Material atau sarana dan prasarana dalam proses perencanaan di Dinas Kesehatan Kabupaten Lampung Timur yaitu terdapat bangunan/gedung yang terdiri dari ruangan Kepala Seksi Kefarmasian, ruangan staf kefarmasian serta ruangan penyimpanan obat dan alat kesehatan atau gudang obat dan alat kesehatan. Luas bangunan kurang lebih 600 metet persegi sedangkan luas tanahnya kurang lebih 800 meter persegi.

Proses perencanaan dilakukan di ruangan staf kefarmasian, di ruangan staf terdapat sarana berupa meja dan kursi. Sedangkan di ruangan /gudang obat terdapat srana berupa lemari obat berjumlah 10 buah, rak obat berjumlah 27 buah, pallet berjumlah 110 buah, Lemari pendingin 2 buah, cold chain 8 buah,

Hasil observasi mengenai Machine atau alat pendukung proses perencanaan terdapat komputer dan printer masing-masing 2 (dua) buah yang cukup baik dan memadai untuk membuat dan mencetak dokumen perencanaan atau RKO.

\section{Proses}

Hasil Wawancara dengan staf di Seksi Kefarmasian Dinas Kesehatan Kabupaten Lampung Timur mengenai proses perencanaan obat atau pembuatan Rencana Kebutuhan Obat (RKO) Dinas Kesehatan, beliau mengatakan :

"Acuan RKO dari Puskesmas, dibuat rekpan, kita rancang kebutuhannya kemudian kita adakan untuk pengadaan di 2020".

Wawancara dengan staf lain di seksi kefarmasin (staf perencanaan) menjelaskan bahwa :

"Pengelola obat puskesmas menghitung rerata obat yg habis setiap bulannya dikali 18 untuk buffer stock, dilihat lagi stock yang ada di puskesmas sehingga dapat ditentukan kebutuhan real di puskesmas."

Selain itu beliau juga mengatakan mengenai metode dalam perencanaan dan waktu pembuatan RKO :

"Menggunakan metode konsumsi, perencanaan dilakukan awal tahun ".

Dari hasil FGD, pengelola obat juga menjelaskan mengenai proses perencanaan bahwa

"Melihat pemakaian obat sebelumnya, menentukan pemakaian rata-rata perbulan, menjumlahkan pemakaian rata-rata dengan periode pengadaan obat ditambah dengan buffer stok disesuaikan dengan pola penyakit yg mungkin muncul'.

Dari hasil wawancara, FGD dan telaah dokumen dapat disimpulkan bahwa proses perencanaan obat di Dinas Kesehatan Kabupaten Lampung Timur berawal dari kompilasi RKO puskesmas, menggunakan metode konsumsi, disesuaikan dengan pola penyakit yang muncul dan perencanaan dilakukan di awal tahun.

\section{Output}

Wawancara dengan Kepala Seksi Kefarmasian, beliau mengatakan bahwa :

"Proses perencanaan obat disusun berdasarkan RKO Puskesmas yang dikumpulkan dan disusun menjadi RKO Dinas Kesehatan ".

Dari hasil telaah dokumen di temukan RKO Dinas Kesehatan yang merupakan hasil rekapan aatau kompilasi dari RKO puskesmas yang ada di wilayah Dinas Kesehatan Kabupaten Lampung. Dari hal tersebut dapat disimpulkan bahwa output dari perencanaan adalah di hasilkannya rencana kebutuhan obat (RKO) Dinas Kesehatan. 


\section{Pengadaan \\ Input}

Wawancara dengan Kepala Bidang Sumber Daya Kesehatan Dinas Kesehatan Kabupaten Lampung Timur tentang Man atau sumber daya manusia pada bagian pengadaan :

"Yang melaksanakan pengadaan tentu kita ada pejabat pengadaan, PPTK dan PPK." .

Wawancara dengan Kepala Seksi Kefarmasian mengenai siapa saja yang terlibat dalam pengadaan obat, beliau mengatakan:

"KPA, PPK dan Pejabat pengadaan "

Senada yang disampaikan staf seksi kefarmasian (staf perencanaan) bahwa " $Y g$ terlibat pejabat pengadaan, PPK dan KPA".

Dari hasil telaah dokumen pada surat pesanan tertera nama PPK dan pejabat pengadaan. Hasil wawancara dan telaah dokumen menunjukkan bahwa Man atau sumber daya manusia pada bagian pengadaan adalah KPA, PPK dan pejabat pengadaan.

Wawancara dengan Sekretaris BPKAD Lampung Timur mengenai Money atau danaanggaran untuk pengadaan obat di Dinas Kesehatan diperoleh keterangan

“ BPKAD yang menganggarkan karena ada posisi penganggaran, Dinas yang mengajukan, BPKAD sbgi salah satu tim dalam TPAD (Tim Perencanaan Anggaran Daerah), posisi sebagai bendahara daerah, Uang APBD untuk mencukupi semua sektor, menyesuaikan dengan kondisi keuangan pada saat itu”.

Wawancara dengan Kepala Bappeda mengenai anggaran pengadaan obat:

" Bappeda merencanakan anggaran pengadaan obat berdasarkan usulan Dinas Kesehatan tetapi tidak semua yang diusulkan dipenuhi karena melihat kemampuan keuangan daerah".

Keterangan lainnya mengenai dana anggaran pengadaan obat diperoleh dari Kepala Dinas Kesehatan Kabupaten Lampung Timur :

"Sumber anggaran untuk pengadaan obat sebetulnya dari APBN dan APBD, tapi untuk dana $A P B D$ di refocusing untuk penanganan covid sehingga anggaran untuk pengadaan obat PKD tahun 2020 bersumber dari DAK $(A P B N)$ "

Dari hasil wawancara tersebut dapat disimpulkan Money atau dana pengadaan obat dianggarkan dari APDD dan DAK/APBN.

Wawancara dengan Kepala Dinas Kesehatan mengenai Methode dalam pengadaan obat :
"Pengadaan obat tahun 2020 dilakukan oleh PPK melalui sistem e-catalogue / epurchaising".

Keterangan lain terkait dengan methode diperoleh dari hasil wawancara dengan staf seksi kefarmasian, beliau mengatakan :

"Menggunakan e purchasing, dan pengadaan langsung"

Dari hasil wawancara diatas dapat disimpulkan bahwa methode pada pengadaanobat adalah melalui sistem $e$ catalogue / e purchasing.

Proses pengadaan dilkukan di ruangan Kepala Seksi Kefarmasian dimana beliau juga menjabat sebagai pejabat pengadaan, di ruangan Kepala Seksi Kefarmasian dilengkapi meja dan kursi yang cukup memadai.

Hasil observasi mengenai Machine atau alat pendukung proses pengadaan obat terdapat jaringan internet, komputer dan printer .

\section{Proses}

Wawancara dengan Kepala Dinas Kesehatan terkait proses pengadaan obat di Dinas Kesehatan Kabupaten Lampung Timur :

"Pengadaan obat tahun 2020 dilakukan oleh PPK dinkes Lamtim melalui sistem ecatalog / e-purchaising".

Wawancara dengan Kepala Bidang SDK yang juga sebagai Pejabat Pembuat Komitmen atau PPK didapatkan penjelasan bahwa

"Terkait dengan proses pengadaan obat yang dilaksanakan Dinas Kesehatan Lampung Timur itu pertama berdasarkan pada DPA dan kedua berdasarkan RKO yang dibuat oleh puskesmas, kemudian kita melakukan pesanan obat ke pihak penyedia dalam hal ini terkait dengan obat kita pemesanannya hanya ke PBF tidak boleh diluar PBF, proses pengadaan kemudian sesuai dengan kebutuhannya dibuat kontrak dan nominal harga sudah sesuai dengan ketentuan standarnya yg dikeluarkan oleh PBF dan juga mengacu juga kebutuhan obat ini berdasarkan FORNAS (Formularium Nasional)".

Kepala Seksi Kefarmasian yang juga sebagai pejabat pengadaan menerangkan bahwa

"Proses pengadaan berdasarkan RKO yang sudah disusun kemudian menyusun harga perkiraan sendiri (HPS) yang disusun oleh PPK, baru mengadakan proses pengadaan"

Dari hasil observasi dan telaah dokumen ditemukan surat pesasan $e$ catalog yang menunjukkan bahwa pemesanan obat untuk 
pengadaan obat tahun 2020 melalui $e$ purchasing/e catalogue.

Pengadaan obat harus mengacu pada FORNAS dan e catalog, terdapat kendala dalam memenuhi pengadaan yang sesuai kebutuhan obat puskesmas, seperti yang di sampaikan Kepala Seksi Kefarmasian yang juga berperan sebagai pejabat pengadaan bahwa

"Obat-obat yg kita beli terbatas hanya yang ada di e catalog dan FORNAS khusus faskes 1 jadi obat-obatannya terbatas, ada kalanya obat 2 yang kita butuhkan itu tdk ada di e catalog, untuk yg non e catalog harganya mahal jadi jumlah obat yang di peroleh lebih sedikit".
Hal serupa dikemukakan beberapa pengelola obat dalam FGD :

Pengelola obat Puskesmas Sekampung menyatakan bahwa :

"Keterbatasan fornas dan e catalog sehingga ada beberapa obat yang dibuthkan dokkter tidak dapat di beli"

Pengelola obat Puskesmas Margototo mengatakan hal yang sama:

"Dinas terkendala e catalog dan fornas, pengelompokam faskes tdk mengakomodir kebutuhan obat puskes rawat inap, persediaan obat2 di e catalog tdk lengkap Meskipin RKO sdh bagus tetapi mau beli obatnya tidak ada di e catalog"

Tabel 1 Hasil Penelitian Input, Proses dan Output pada perencanaan, dan obat di Dinas Kesehatan Kabupaten Lampung Timur

\begin{tabular}{|c|c|c|c|}
\hline \multirow{2}{*}{$\begin{array}{c}\text { Pengelolaan } \\
\text { Obat }\end{array}$} & \multicolumn{3}{|c|}{ IPO } \\
\hline & Input & Proses & Output \\
\hline Perencanaan & $\begin{array}{l}\text { Man : Tim Perencanaan Obat Dinas } \\
\text { Kesehatan : Kepala Seksi (S2 } \\
\text { Kesmas) dan Apoteker } \\
\text { Money (sumber dana) : APBN/DAK } \\
\text { Methode : SOP Perencanaan, } \\
\text { FORNAS } \\
\text { Material : ruangan staf seksi } \\
\text { kefarmasian } \\
\text { Machine: komputer dan printer }\end{array}$ & 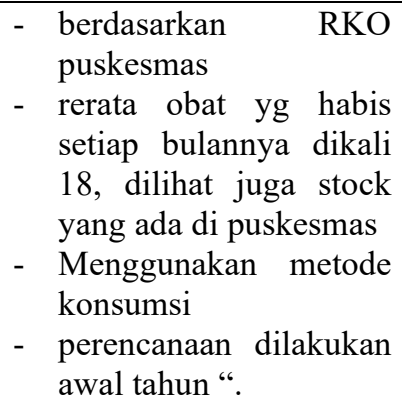 & $\begin{array}{l}\text { RKO } \\
\text { Kesehatan }\end{array}$ \\
\hline Pengadaan & $\begin{array}{l}\text { Man : PA atau KPA, PPk dan pejabat } \\
\text { pengadaan } \\
\text { Money (sumber dana) : APBD, } \\
\text { APBN } \\
\text { Methode : e purchasing / e catalog } \\
\text { Material : ruangan Kepala Seksi } \\
\text { Kefarmasian } \\
\text { Machine : komputer, printer dan } \\
\text { layanan internet }\end{array}$ & $\begin{array}{ll}\text { - } & \text { berdasarkan FORNAS } \\
\text { (Formularium Nasional } \\
\text { - } & \text { berdasarkan pada DPA } \\
\text { - } & \text { berdasarkan RKO } \\
\text { Dinas Kesehatan yang } \\
\text { telah disetujui Kepala } \\
\text { Dinas Kesehatan } \\
\text { - } \text { proses pengadaan } \\
\text { melalui e purchasing / } \\
\text { e catalogue } \\
\text { dibuat konttrak dengan } \\
\text { penyedia } \\
\text { - Pengadaan biasanya } \\
\text { dimulai bulan Maret- } \\
\text { April, , } \\
\text { masa konttrak } 120 \text { hari, }\end{array}$ & $\begin{array}{lr}\text { Adanya } & \text { kontrak } \\
\text { antara PPK } & \text { dengan } \\
\text { penyedia } & \end{array}$ \\
\hline
\end{tabular}

Mengenai apakah perencanaan dan pengadaan obat yang dilakukan Seksi Kefarmasian Dinas Kesehatan Lampung Timur tahun 2020 sudah sesuai atau belum dengan perencanaan dan kebutuhan puskesmas dari hasil FGD pengelola obat puskesmas didapatkan keterangan bahwa :

"Beberapa item obat yang diperlukan tidak terpenuhi, beberapa item jumlahnya masih ada yang berlebih dan ada yang kurang”. bahwa :

Pengelola obat yang lain meyebutkan

"Kalo urusan sesuai kebuuhan banyak yg tidak sesuai ".

Dalam hal menanggulangi permasalahan diatas ada beberapa upaya yang dilakukan seperti keterangan yang diberikan oleh Kepala Bidang SDK yang juga sebagai PPK menyebutkan bahwa: 
"Puskesmas sudah BLUD sehingga untuk mengatasi kebutuhan obat yg tidak terakomodir atau tidak bisa diadakan oleh Dinas Kesehatan maka puskesmas dapat menggunakan anggaran BLUD dengan skala prioritas, terus berupaya untuk meningkatkan anggaran, ada droping dari provinsi untuk obat2an tertentu"

\section{Output}

Wawancara dengan Kepala Seksi

Kefarmasian :

"Pengadaan biasanya dimulai bulan Maret-April, Untuk pemilihan penyedia 7-15 hari, masa konttrak 120 hari, jumlah obat yang diadakan atau di beli tergantung di HPS dan RKO"

Selaras dengan kutipan Kepala SDK tentang pengadaan bahwa :

"proses pengadaan kemudian sesuai dengan kebutuhannya dibuat kontrak"

Dari hasil observasi dan telaah dokumen ditemukan kontrak antara PPK dengan penyedia. Dari hasil wawancara, observasi dan telaah dokumen diperoleh kesimpulan bahwa output dari pengadaan obat adalah adanya kontrak antara PPK dengan penyedia.

\section{PEMBAHASAN}

\section{Perencanaan}

Input

Perencanaan merupakan tahapan untuk menetapkan jenis dan jumlah obat yang dibutuhkan yang akan diadakan / dibeli pada saat pengadaan. Dalam perencanaan diperlukan koordinasi dan keterpaduan antara pemegang program, pihak puskesmas maupun unsur pemerintah daerah. Untuk itu Tim Perencanaan Obat Terpadu kabupaten sangat diperlukan dalam rangka meningkatkan efisiensi dan efektivitas penggunaan dana melalui koordinasi, integrasi dan sinkronisasi antar instansi yang terkait dengan masalah obat di setiap kabupaten/kota.

Hasil penelitian menunjukkan bahwa di Dinas Kesehatan Kabupaten Lampung Timur tidak terdapat Tim Perencanaan Obat Terpadu Kabupaten, hanya ada tim perencanaan obat antar program Dinas Kesehatan yang terdiri dari kepala seksi kefarmasian, apoteker dan pemegang program. Adapun manfaat dari Tim Perencanaan Obat Terpadu ini pada Lampiran tersebut adalah menghindari tumpang tindih penggunaan anggaran, keterpaduan dalam evaluasi, penggunaan dan perencanaan, kesamaan persepsi antara pemakai obat dan penyedia anggaran, estimasi kebutuhan obat lebih tepat, koordinasi antara penyedia anggaran dan pemakai obat serta pemanfaatan dana pengadaan obat dapat lebih optimal.

Penelitian mengenai perencanaan obat yang dilakukan Sulistyorini (2016) bahwa perencanaan kebutuhan obat di Dinas Kesehatan Kabupaten Kediri dilakukan melalui koordinasi dengan tim perencanaan obat dan perbekalan kesehatan kabupaten ${ }^{7}$. Selain itu perencanaan kebutuhan obat juga didasarkan pada usulan perencanaan puskesmas. Pada tahun 2015 tim perencana obat dan perbekalan kesehatan bertemu 1 kali untuk membahas pengadaan obat tahun 2015 .

Penelitian Aisah (2019) menjelaskan bahwa di Dinas Kesehatan Kabupaten Pati Perencanaan obat dilakukan dengan metode konsumsi dan morbiditas, dan terdapat Tim Perencanaan Obat Terpadu (TPOT) untuk menganalisa kebutuhan obat, tetapi proses perencanaan belum berjalan dengan optimal dengan SDM apoteker bagian dari seksi kefarmasian dan alkes dan jumlah SDM Apoteker di Puskesmas terbatas ${ }^{8}$. Penelitian lainnya menunjukkan bahwa perencanaan obat di GFK Gunung Mas belum berjalan baik, hal ini disebabkan karena belum didukung kemampuan petugas yang memadai serta kepatuhan petugas rendah dalam menjalankan pedoman perencanaan. Pendidikan petugas memenuhi ketentuan yaitu pendidikan kefarmasian, sebagian besar pengetahuan petugas sebatas definisi dan kriteria obat, beban kerja petugas GFK berlebihan ${ }^{9}$. Sistem Informasi Perencanaan Pengadaan Obat Dinas Kesehatan Kabupaten telah berfungsi degnan baik sehingga diharapkan dapat membantu pemerintah daerah dalam mengambil keputusan untuk melakukan perencanaan pengadaan obat tahun berikutnya. Dengan menggunakan Sistem Informasi Perencanaan Pengadaan Obat ini dapat diketahui jumlah obat yang direncanakan untuk dipesan secara efektif ${ }^{10}$.

Hasil wawancara dengan stakeholder di Kabupaten Lampung Timur menyatakan bahwa diperlukan Tim Perencanaan Obat Terpadu Kabupaten agar perencanaan obat terkoordinasi degan baik.

Dengan belum terbentuknya Tim Perencanaan Obat Terpadu Kabupaten, peneliti melihat perencanaan obat di Dinas Kesehatan Kabupaten Lampung Timur belum terkoordinasi dengan baik antara Dinas Kesehatan, Puskesmas maupun pemeganng 
program di Dinas Kesehatn, dengan adanya kelebihan stok, kekurangan maupun ketidaktersediaan obat oleh karena itu perlu dibentuk Tim Perencanaan Obat Terpadu Kabupaten Lampung Timur.

Berdasarkan Permenkes RI Nomor 51

Tahun 2019 tentang Penyelenggaraan Pekerjaan Kefarmasian bahwa Pengadaan Sediaan Farmasi harus dilakukan oleh Tenaga kefarmasian. Hasil wawancara sesuai dengan hasil observasi yaitu bahwa di Seksi Kefarmasian terdapat tenaga kefarmasian sebanyak 3 (tiga) orang. Tenaga kefarmasian di Seksi Kefarmasian Dinas Kesehatan Lampung Timur sudah mencukupi maka peneliti mengusulkan pembagian tugas pokok dan fungsi masing-masing tenaga kefarmasian yang lebih jelas sehingga pengelolaan obat di Seksi Kefarmasian dapat dilaksanakan dengan lebih baik.

Penelitian Syanti R (2020) menjelaskan bahwa penyusunan perencanaan obat di Dinas Kesehatan Kabupaten Padang Pariaman sudah dianggarkan dana yang dialokasikan dalam anggaran APBD yang dimasukkan dalam Program Pengadaan Obat dan Perbekalan Kesehatan yang besarannya sesuai dengan kebutuhan dan masih dalam batas kewajaran ${ }^{11}$.

Hasil wawancara di Dinas Kesehatan

Kabupaten Lampung Timur tentang Money atau dana perencanaan obat tahun 2020 dengan Kepala Dinas Kesehatan bahwa awalnya dana pengadaan obat tahun 2020 berasal dari APBD dan APBN/DAK, namun karena adanya pendemi covid 19 maka dana APBD di refokusing untuk penanganan covid 19 sehingga anggaran untuk pengadaan obat $\mathrm{PKD}$ tahun 2020 bersumber dari DAK /APBN.

Tidak terpenuhinya dana anggaran perencanaan obat sesuai RKO menyebabkan RKO harus menyesuiakan dengan dana yang ada sehingga beberapa item obat dan jumlah mengalami pengurangan dalam perencanaan pembelanjaannya. Hal ini salah satu yang menyebabkan tidak terpenuhinya semua kebutuhan obat untuk puskesmas. Namun dari hasil wawancara dengan Kabid SDK bahwa untuk item obat yang tidak bisa di adakan oleh Dinas Kesehatan atau jumlah obat yang kurang, Puskesmas dapat merencanakan pembelanjaan lewat dana BLUD Puskesmas.

Hasil penelitian terdapat Methode atau Standar Operasional Prosedur Perencanaan dan daftar obat dalam perencanaan obat atau RKO sesuai dengan Permenkes no.74 tahun 2016
Tentang Standar Pelayanan Kefarmasian Di Puskesmas dan Peraturan Menteri Kesehatan No.HK. 01.07/MENKES/813/2019 Tentang Formularium Nasional. Hasil penelitian terhadap Material atau sarana dan prasarana, Seksi Kefarmasian Dinas Kesehatan Kabupaten Lampung Timur memiliki sarana berupa bangunan dengan luas kurang lebih 600-meter persegi dan luas tanah sekitar 800 meter persegi. Bangunan terdiri dari ruangan Kepala Seksi Kefarmasian, ruangan staf dan ruangan penyimpanan / gudang obat dan alat kesehatan.

Prasarana yang terdapat di ruangan Kepala Seksi dan ruangan staf adalah meja dan kursi dengan jumlah total 8 set. Sedangkan di ruangan /gudang obat terdapat sarana berupa lemari obat berjumlah 10 buah, rak obat berjumlah 27 buah, pallet berjumlah 110 buah, Lemari pendingin 2 buah, cold chain 8 buah, pengatur udara berupa AC berjumlah 12 buah, troli 4 buah, generator 1 buah, alat pemadam kebakaran 2 buah.

Berdasarkan Standar Sarana Penyimpanan Obat Publik Dan Perbekalan Kesehatan, Depkes RI, 2005 disebutkan bahwa luas bangunan minimal 300 meter persegi dan luas tanah 500 - 3000 meter persegi. Selain itu juga disebutkan jumlah minimal untuk sarana yang ada di ruang penyimpanan obat/gudang obat adalah lemari obat berjumlah 2 atau 3 buah, rak obat 20 sampai 35 unit, pallet 20 sampai 25 buah, lemari pendingin 2 buah, cold chain 2 buah, tangga 2 buah, pengatur udara (Ac) 2 buah, mebeulair 2set, troli 2 buah, generator 1 buah dan alat pemadam kebakaran 1-2 buah

Dari data-data diatas peneliti melihat bahwa sarana dan prasarana yang terdapat di Seksi Kefarmasian Dinas Kesehatan Lampung Timur sudah mencukupi dan sesuai standar minimal yang ditetapkan.

Machine atau alat penunjang dalam perencanaan obat sudah mencukupi dan sesuai kebutuhan yaitut terdapat dua buah komputer dan dua buah printer dimana pada Standar Sarana Penyimpanan Obat Publik Dan Perbekalan Kesehatan, Depkes RI, 2005, minimal pengolah data adalah komputer minimal 1 buah dan printer permanen ( non portable) jumlah 1 buah.

\section{Proses}

Proses perencanaan obat di Dinas Kesehatan Kabupaten Lampung Timur sudah sesuai dengan pedoman teknis pengadaan obat publik dan perbekalan kesehatan pada 
Lampiran Keputusan Menteri Kesehatan Nomor 1 121/MENKES/SK/XII/2008. Setiap awal tahun staf perencanaan obat Dinas Kesehatan Kabupaten Lampung Timur meminta pengelola obat puskesmas untuk membuat Rencana Kebutuhan Obat (RKO) puskesmas, dengan memberikan form RKO dan pengelola obat mengisi kolom pemakasian obat rata-rata perbulan. Dari hasil wawancara dan FGD dapat diketahhui bahwa proses perencanaan obat di Dinas Kesehatan berdasarkan rencana kebutuhan obat (RKO) puskesmas, hal ini sudah sesuai dengan bottom up planning dalam menyusun perencanaan kebutuhan.

Penelitian yang dilakukan oleh Walujo (2018) menjelaskan bahwa perencanaan kebutuhan obat di Instalasi Farmasi Dinas Kesehatan Kota Kediri dilakukan melalui koordinasi dengan tim perencanaan obat dan perbekalan kesehatan kota ${ }^{12}$. Sumber data yang digunakan Dinas Kesehatan Kota Kediri berawal dari rekapan data pemakaian obat yang dicatat dalam laporan pemakaian obat bulanan Laporan Pemakaian dan Lembar Permintaan Obat (LPLPO) untuk menentukan jenis obat dari masing-masing UPT Puskesmas beserta usulan Puskesmas Pembantunya di Kota Kediri.

Penyusunan perencanaan kebutuhan obat atau RKO Dinas Kesehatan Kabupaten Lampung Timur seperti disebutkan dalam SOP Perencanaan adalah merupakan rekapan dari RKO seluruh puskesmas yang ada di wilayah kerja Dinas Kesehatan Kabupaten Lampung Timur, apabila penyusunan RKO di tingkat puskesmas tidak disusun dengan baik dan tidak berdasarkan data yang akurat maka RKO Dinas pun tidak akan menghasilkan perencanaan yang baik, oleh karena itu pengelola obat puskesmas dituntut untuk membuat RKO yang dapat mengakomodir kebutuhan obat puskesmas dengan item dan jumlah obat yang sesuai dengan kebutuhan dan berdasarkan data-data yang akurat dan koordinasi yang baik dengan dokter puskesmas.

Hasil telaah dokumen beberapa RKO puskesmas, penelti melihat bahwa item dan jumlah obat yang disusun dalam RKO belum sesuai pemakaian dan kebutuhan puskesmas, ada beberapa obat-obatan yang tidak dipakai oleh dokter tetapi masih dianggarkan di RKO selain itu juga ada beberapa item obat yang jumlahnya melebihi kebutuhan atau over volume, hal ini akan menyebabkan obat-obat tersebut tidak terpakai sehingga menyebabkan pemborosan. Diperlukan analisis dan kejelian dari tim perencanaan obat Dinas Kesehatan dalam merekap RKO puskesmas selain itu pengelola obat juga harus memiliki data pemakaian obat harian dan bulanan (LPLPO) yang real dan data sisa obat di gudang sehingga jumlah obat yang direncanakan dalam RKO benar-benar jumlah yang real dan tidak copy paste RKO tahun lalu. Pengelola obat dituntut untuk memiliki pengetahuan yang baik didalam pengelolaan dan perencanaan kebutuhan obat puskesmas. Untuk itu peneliti menyarankan Dinas Kesehatan Lampung Timur untuk mengadakan pembinaan maupun pelatihan dalam pembuatan Rencana Kebutuhan Obat puskesmas sehingga diharapkan RKO puskesmas yang dibuat menjadi lebih baik.

Penelitian Syanti, 2020, menyebutkan bahwa di Dinas Kesehatan Kabupaten Padang Pariaman ditemukan bahwa sumber data yang dipergunakan dalam penyusunan perencanaan berasal dari laporan puskesmas yaitu LPLPO serta laporan SP2TP. Selain itu sumber data lain yang dipakai adalah data hasil olahan IFK 11.

\section{Output}

Output dari perenanaan obat di Dinas Kesehatan Kabupaten Lampung Timur yaitu dihasilkannya Rencana Kebutuhan obat Dinas Kesehatan. RKO Dinas Kesehatan Kabupaten Lampung Timur merupakan kompilasi data RKO yang disampaikan puskesmas. Hal ini sesuai dengan Lampiran Keputusan Menteri Kesehatan Nomor 1121/MENKES/SK/XII/2008 tentang Pedoman Teknis Pengadaan Obat Publik dan Perbekalan Kesehatan : Proses perencanaan pengadaan obat diawali dengan kompilasi data yang disampaikan Puskesmas kemudian oleh instalasi farmasi kabupaten/kota diolah menjadi rencana kebutuhan obat.

Penelitian Rusman Syanti di Dinas Kesehatan Kabupaten Padang Pariaman (2020) menyebutkan bahwa dokumen perencanaan obat yang dihasilkan adalah Rencana Kebutuhan Obat (RKO) yang berasal dari usulan program dan data dari IFK . RKO Dinas Kesehatan Kabupaten Padang Pariaman berupaya mengacu pada kebutuhan dalam pelayanan kesehatan dasar ${ }^{11}$.

\section{Pengadaan}

Input

Unsur Man atau sumber daya manusia pada proses pengadaan di Dinas Kesehatan Kabupaten Lampung Timur adalah PA atau 
KPA, PPK dan pejabat pengadaan, hal ini sesuai dengan standar dan peraturan yang belaku yaitu Perpres No.16 tahun 2018 Tentang Pengadaan Barang dan Jasa. Yang bertugas sebagai PA/KPA adalah Kepala Dinas Kesehatan Kabupaten Lampung Timur, PPK di jabat oleh Kepala Bidang SDK dan Pejabat Pengadaannya adalah Kepala Seksi Kefarmasian. Kebijakan Perpres No.16 tahun 2018 tentang Pengadaan barang dan jasa ini di terapkan adalah antara lain untuk meningkatkan kualitas perencanaan pengadaan barang/jasa; melaksanakan pengadaan barang/jasa yang lebih transparan, terbuka, dan kompetitif; memperkuat kapasitas kelembagaan dan sumber daya manusia pengadaan barang/jasa; mengembangkan Emarketplace pengadaan barang/jasa; menggunakan teknologi informasi dan komunikasi, serta transaksi elektronik.

Pengadaan obat dan perbekalan kesehatan untuk pelayanan kesehatan dasar (PKD) dibiayai melalui berbagai sumber anggaran. Berbagai sumber anggaran yang membiayai pengadaan obat dan perbekalan kesehatan tersebut antara lain : APBN : Program Kesehatan, Program Pelayanan Keluarga Miskin: APBD I; Dana Alokasi Umum (DAU)/APBD II dan Sumber-sumber lain ( Lampiran Keputusan Menteri Kesehatan Nomor 1121/MENKES/SK/XII/2008 tentang Pedoman Teknis Pengadaan Obat Publik dan Perbekalan Kesehatan ).

Penelitian yang dilakukan oleh Nur Aisah (2019) menjelaskan bahwa untuk memenuhi kebutuhan obat di Dinas Kesehatan Kabupaten Pati, sumber anggaran berasal dari Dana Alokasi Khusus (DAK), APBD I dan Dana Kapitasi ${ }^{8}$.

Didalam Kebijakan Obat Nasional (KONAS) tahun 2006 disebutkan bahwa target pembiayaan obat sektor publik secara nasional adalah 2 US dollar perkapita pertahun (all drugs). Ini sesuai standar yang di tetapkan oleh WHO. Sumber anggaran perencanaan dan pengadaan obat Dinas Kesehatan Kabupaten Lampung Tmur tahun 2020 adalah dari APBN/DAK yaitu sebesar kurang lebih 1,69 milyar. Apabila di hitung dari besar anggaran yang ada untuk pengadaan obat tahun $2020 \mathrm{di}$ Kabupaten Lampung Timur di bandingkan dengan jumlah penduduk Kabupaten Lampung Timur maka biaya obat perkapita sebesar kurang lebih Rp. 1.600,- .

Biaya obat perkapita di Kabupaten lampung Timur masih jauh dari target pemerintah hal ini menurut anggota Komisi IV DPRD Lampung Timur karena jumlah penduduk Kabupaten Lampung Timur yang besar sedangkan APBDnya kecil. Melihat dari biaya obat perkapita di Lampung Timur yang jauh dari target, maka Dinas Kesehatan hendaknya mengusulkan penambahan anggaran pengadaan obat dengan melakukan upayaupaya advoasi kepada Pemerintah Daerah Kabupaten Lampung Timur. Dana anggaran pengadaan obat di Dinas Kesehatan Lampung Timur tahun 2020 sebenarnya tidak hanya dari DAK/APBN tetapi juga dari APBD tetapi karena tahun 2020 awal adanya pandemi covid19, dana APBD mengalami refokusing untuk penanganan covid-19 sehingga anggaran pengadaan obat hanya berasal dari dana DAK/APBN. Hasil penelitian lainnya menunjukan kebijakan pengelolaan anggaran daerah dimasa pandemi Covid-19 pada Pemerintah Daerah Provinsi Banten bahwa, Pemerintah Daerah Provinsi Banten telah menjalankan pengelolaan anggaran sesuai dengan arahan dan kebijakan yang telah diatur oleh pemerintah pusat melalui mekanisme refocusing dan realokasi anggaran pendapatan daerah, belanja daerah, dan pembiayaan daerah secara tepat ${ }^{13}$.

Methode yang digunakan pada proses pengadaan obat di Dinas Kesehatan Kabupaten Lampung Timur adalah dengan sitem $e$ purchasing / e catalogue sesuai dengan PMK No.63/ 2014 tentang pengadaan obat dengan $e$ cataogue. Untuk obat-obat yang tidak ada di $e$ catalogue dapat dilakukan pengadaan secara manual.

Penelitian yang dilakukan oleh Cahyani (2019) menjelaskan bahwa setelah melalui beberapa seleksi dan evaluasi melalui katalaog elektronik obat, maka PPK membuat daftar obat yang dibutuhkan, dan selanjutnya disampaikan kepada pokja Unit Layanan Pengadaan (ULP) untuk segera membuat paket pembelian obat dalam aplikasi epurchasing berdasarkan daftar pengadaan obat ${ }^{14}$.

Unsur Material atau sarana dan prasarana dalam proses pengadaan, proses pengadaan obat dilakukan di ruangan Kepala Seksi Kefarmasian dimana Kepala Seksi juga menjabat sebagai pejabat pengadaan. Sarana yang terdapat di ruangan adalah meja dan kursi berjumlah satu set.

Unsur Machine atau alat penujang pada proses pengadaan di Dinas Kesehatan Kabupaten Lampung Timur adalah komputer 
dan printer yang berjumlah masing-masing satu buah dan terdapat jaringan internet untuk mendukung pengadaan melalui sistem $e$ purchasing.

\section{Proses}

Berdasarkan Peraturan Presiden Nomor 95 tahun 2007 bahwa pekerjaan pengadaan dan distribusi bahan obat, obat dan alat kesehatan dalam rangka menjamin ketersediaan obat untuk pelaksanaan peningkatan pelayanan kesehatan kepada masyarakat yang jenis, jumlah dan harganya telah ditetapkan oleh Menteri Kesehatan dimasukkan kedalam kriteria barang/jasa khusus. Tujuan pengadaan obat dan perbekalan kesehatan adalah tersedianya obat dan perbekalan kesehatan dengan jenis dan jumlah yang cukup sesuai kebutuhan pelayanan kesehatan, mutu obat dan perbekalan kesehatan terjamin, obat dan perbekalan kesehatan dapat diperoleh pada saat diperlukan.

Proses pengadaan obat Pelayanan Kesehatan Dasar di Dinas Kesehatan Kabupaten Lampung Timur tahun 2020 dilaksanakan melaui e purchasing/ e catalogue serta sesuai dengan Perpres No.16 tahun 2018 Tentang Pengadaan barang dan jasa bahwa yang terlibat dalam proses pengadaan adalah KPA, PPK dan pejabat pengadaan. Proses Pengadaan obat di Seksi Kefarmasian Dinas Kesehatan Kabupaten lampung Timur dilaksanakan setahun sekali setelah Rencana Kebutuhan Obat /RKO Dinas disetujui oleh Kepala Dinas. Kepala Dinas mendelegasikan pengadaan obat berdasarkan RKO yang telah disetujui kepada Pejabat Pembuat Komitmen ( PPK ). PPK dan Pejabat Pengadaan melakukan pengadaan berdasarkan e-purchasing katalog elektronik sesuai Permenkes No.5 Tahun 2019 dan Perpres No.16 tahun 2018. Proses pengadaan dimulai sekitar bulan Mei dan Juni sedangkan obat mulai dikirim sekitar bulan Juli atau berdasarkan kesepakatan kontrak antara penyedia dengan PPK.

Sesuai Pasal 11 Peraturan Presiden Nomor 16 Tahun 2018 tentang Pengadaan Barang/Jasa Pemerintah, pengadaan obat melalui e-purchasing bisa dilakukan oleh PPK (Pejabat Pembuat Komitmen) dan Pejabat Pengadaan yang ditunjuk oleh Kepala Dinas Kesehatan dengan ketentuan : PPK melaksanakan e-purchasing yang bernilai paling sedikit diatas Rp200.000.000,00 sedangkan Pejabat pengadaan melaksanakan $e$ - purchasing yang bernilai paling banyak Rp200.000.000,00

Hasil Penelitian Mukhlis T (2016) menyebutkan bahwa proses pengadaan obat di Dinas Kesehatan Kota Lhokseumawe diawali dengan perencanaan obat yang telah dibuat oleh tim perencana obat. Setelah melalui beberapa seleksi dan evaluasi melalui katalog elektronik obat, maka PPK membuat daftar obat yang dibutuhkan, dan selanjutnya disampaikan kepada pokja Unit Layanan Pengadaan (ULP) untuk segera membuat paket pembelian obat dalam aplikasi e-purchasing berdasarkan daftar pengadaan obat ${ }^{15}$. Walujo dkk (2018) dalam penelitiannya menyebutkan pengadaan yang dilakukan oleh Instalasi Farmasi Dinas Kesehatan Kota Kediri menggunakan pengadaan secara elektronik atau $E$ Procurement dengan E-Purchasing. menggunakan penentuan jumlah obat yang dibutuhkan dengan metode konsumsi dan buffer stock, yaitu pemakaian rata-rata tahun $\mathrm{x} 18$ bulan $^{12}$. Kemudian, penelitian lainnya menunjukkan bahwa kinerja e-procurement obat dengan prosedur e-purchasing berdasarkan e-catalogue berpengaruh terhadap efisiensi pengadaan obat dengan nilai signifikasi 0,001 16.

Dalam pemilihan jenis obat yang akan diadakan atau dibeli mengacu pada FORNAS sesuai dengan Peraturan Menteri Kesehatan No.HK. 01.07/MENKES/813/2019 tentang Formularium Nasional dan daftar obat di $e$ catalogue sesuai Permenkes RI No.48 tahun 2013 tentang Petunjuk Pelaksanaan Pengadaan Obat Dengan Prosedur E-Purchasing Berdasarkan E-Catalogue.

Untuk obat yang dibutuhkan tetapi tidak ada di e catalogue dapat di adakan atau dibeli dengan pengadaan manual asalkan obat tersebut ada dalam FORNAS, namun obat di luar e catalogue harganya lebih mahal. Untuk obat yang tidak ada di FORNAS, Dinas Kesehatan tidak dapat membeli atau mengadakannya. Dengan adanya ketentuan di atas menjadi kendala Dinas Kesehatan dalam upaya memenuhi tersedianya obat dan perbekalan kesehatan dengan jenis dan jumlah yang cukup sesuai kebutuhan puskesmas sehingga diharapkan Kementerian Kesehatan RI dapat memuat semua obat-obatan yang dibutuhkan fasilitas kesehatan kedalam daftar obat e catalogue dan formularium nasional (FORNAS). 


\section{Output}

Berdasarkan Perpres No.16 tahun 2018 Tentang Pengadaan barang dan jasa bahwa penyedia wajib memenuhi kualifikasi sesuai dengan barang/jasa yang diadakan dan sesuai dengan ketentuan peraturan perundangundangan. Penyedia bertanggung jawab atas pelaksanaan Kontrak, kualitas barang/jasa, ketepatan perhitungan jumlah atau volume, ketepatan waktu penyerahan dan ketepatan tempat penyerahan. Dari hasil penelitian diperoleh keterangan bahwa output pada pengadaan di Dinas kesehatan Kabupaten Lampung Timur sudah sesuai Perpres No.16 tahun 2018 tentang pengadaan barang dan jasa yaitu dihasilkannya kontrak dengan penyedia.

\section{KESIMPULAN DAN SARAN}

Perencanaan Obat di Dinas Kesehatam Kabupaten Lampung Timur Tahun 2020 dimulai dengan kompilasi RKO Puskesmas sesuai bottom up planning. Penyusunan obat dalam RKO mengacu pada FORNAS sesuai dengan Permenkes No. HK. 01.07/MENKES/813/2019. Adapun pengadaan obat menggunakan sistem Katalog Elektronik (e catalogue), sesuai dengan PMK No.63/2014.

Masalah dalam perencanaan obat di Dinas Kesehatam Kabupaten Lampung Timur Tahun 2020 adalah perhitungan jumlah kebutuhan obat belum sesuai dengan kebutuhan puskesmas. Dalam pengadaan ada beberapa obat yang tidak dapat diadakan karena tidak ada di e catalog atau FORNAS. Solusi untuk perencanaan obat adalah dilakukan analisis data pemakaian obat yang akurat. Untuk pengadaan obat yang tidak ada di e catalogue dan FORNAS dapat dilakukan pengadaan secara manual.

Adapun saran penelitian yaitu perlu dibentuk Tim Perencanaan Obat Terpadu Kabupaten Lampung Timur dalam rangka meningkatkan efisiensi dan efektivitas penggunaan dana melalui koordinasi, integrasi dan sinkronisasi antar instansi yang terkait dengan masalah obat di Kabupaten Lampung Timur. Perlu dilakukan pembinaan atau pelatihan untuk pengelola obat puskesmas tentang penyusunan rencana kebutuhan obat (RKO) sehingga pembuatan RKO Puskesmas dapat lebih akurat dan sesuai kebutuhan puskesmas.

\section{DAFTAR PUSTAKA}

1. Kemenkes RI. Materi Pelatihan Manajemen Kefarmasian di Instalasi Farmasi Kabupaten/Kota. Direktorat Bina Obat Publik dan Perbekalan Kesehatan, Direktorat Jenderal Bina Kefarmasian dan Alat Kesehatan, Kementrian Kesehatan RI. 2010.

2. Depkes RI. Pedoman Teknis Pengadaan Obat Publik dan Perbekalan Kesehatan Untuk Pelayanan Kesehatan Dasar (PKD). Direktorat Jenderal Pelayanan Kefarmasian dan Alat Kesehatan, Departemen Kesehatan RI. 2002.

3. JDIH BPK RI. PERPRES No. 72 Tahun 2012 tentang Sistem Kesehatan Nasional. Database Peraturan. p. 2012.

4. Kemenkes RI. Rencana Strategis Kementerian Kesehatan Tahun 2015-2019. 1st ed. 2017.

5. Asnawi R, Kolibu FK, Maramis FRR, Kesehatan F, Universitas M, Ratulangi S, et al. Analisis Manajemen Pengelolaan Obat Di Puskesmas Wolaang. Jurnal KESMAS. 2019;8(6).

6. Lapau B. Metode Penelitian Kesehatan, Metode Ilmiah Penulisan Skripsi, Tesis dan Disertasi. Jakarta: Pustaka Obor Indonesia; 2012.

7. Sulistyorini A. Perencanaan Obat Dengan Menggunakan Metode Konsumsi Di Dinas Kesehatan Kabupaten Kediri. Jurnal Penelitian Kesehatan "SUARA FORIKES" (Journal of Health Research "Forikes Voice"). 2016 Jul 31;7(3):112-20.

8. Aisah N, Satibi S, Suryawati S. Evaluasi Pengelolaan Obat pada Tahap Perencanaan dan Pengadaan di Dinas Kesehatan Kabupaten Pati. Majalah Farmaseutik. 2020 Jan 30;16(1):34-42.

9. Triana M, Suryawati C, Sriyatmi A. Evaluation on Drug Planning for Basic Health Services at Pharmaceutical Warehouses of Gunung Mas District, Central Kalimantan. Jurnal Manajemen Kesehatan Indonesia. 2014;2(1):44-51.

10. Rahmawatie E, Santosa S. Sistem Informasi Perencanaan Pengadaan Obat Di Dinas Kesehatan Kabupaten Boyolali. Jurnal Pseudocode. 2015;2(1):45-52.

11. Syanti R. Analisis Sistem Penyusunan Perencanaan Obat Di Dinas Kesehatan Kabupaten Padang Pariaman. Human Care Journal. 2020;5(1):411-20.

12. Walujo DS, P EY, A SFASF. Analisis Perencanaan Obat Dengan Menggunakan Metode Konsumsi Di Instalasi Farmasi Dinas Kesehatan Kota Kediri Tahun 2017. Jurnal Wiyata: Penelitian Sains dan Kesehatan. 2018 Sep 22;5(1):24-8.

13. Sanjaya N. Regional Budgeting Policy In The Covid-19 Pandemic Era (Case Study at the 
Regional Government of Banten Province). Jurnal Ilmu Administrasi. 2020;17(2):273-90.

14. Cahyani HF, Ulfa AM, Angelina CF. Evaluasi Manajemen Pengelolaan Obat Di Dinas Kesehatan Kabupaten Mesuji Tahun 2019. JURNAL DUNIA KESMAS. 2020 May 17;9(2):288-300.

15. Mukhlis T. Manajemen Pengelolaan Obat Di Dinas Kesehatan Kota Lhokseumawe Tahun 2016 [Internet]. [Medan]: Universitas Sumatera Utara; 2016 [cited 2021 Dec 6]. Available from: https://repositori.usu.ac.id/handle/123456789 1671

16. Sutriatmoko, Satibi, Puspandari DA. Analysis of drug e-procurement application with epurchasing procedures based on e-catalogue in the district/city of health division in Central Java. Jurnal Manajemen dan Pelayanan Farmasi. 2015;5(4):275-82. 